
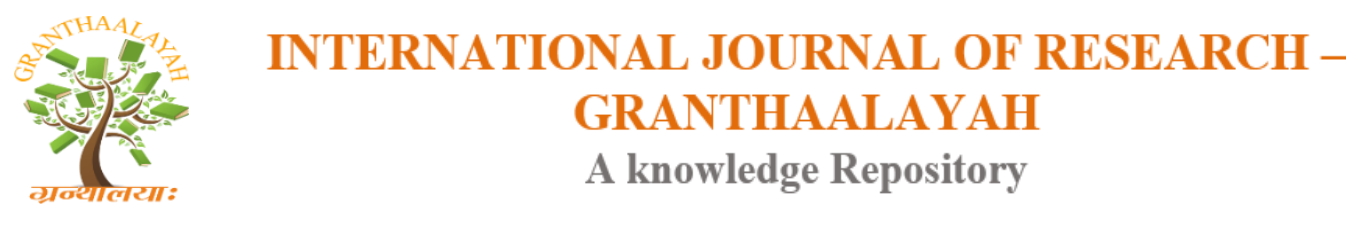

Social

\title{
MEDIA AND DEMOCRATIC GOVERNANCE IN NIGERIA
}

\author{
Ola Abegunde ${ }^{1}$, Olatunde J. Fajimbola ${ }^{2}$ \\ ${ }^{1}$ Ph.D, Department of Political Science, Ekiti State University, Ado-Ekiti, Nigeria \\ ${ }^{2}$ Department of Political Science, Joseph Ayo Babalola University, Ikeji Arakeji, Osun State, \\ Nigeria
}

\begin{abstract}
Democracy as a concept has become a common term among the generality of Nigerian citizens as a result of its frequent usage in the media. Although in the real sense of it, it has brought little dividends to Nigerians. In spite of its popular acceptance as the most favourable form of government in the world, the media in Nigeria has portrayed democracy in an uninspiring manner because of the greed, corruption and nepotism of Nigerian politicians thereby making the political communication of democracy as government of the people by the people and for the people unimpressive. Therefore, this paper examines the linkage between the media and democratic governance in Nigeria. It seeks to understand the ills that the media had caused to the democratic governance in Nigeria through sensational coverage of political events. The paper relied on secondary sources of data collection; and it is descriptive and explanatory in nature. The study anchored on Political Communication theory and Agenda-Setting theory to explain the influence of the media on democracy. The findings showed that Nigerian media is faced with myriads of challenges in fulfilling its duty as the watchdog of the society due to the issue of ownership, economic problem, and lack of adherence to professional ethics. It therefore recommended that adequate training that will reflect the ethics of the profession be given to media practitioners and other relevant stakeholders. Also, media practitioners including owners of medial houses should be exposed to an all-embracing political education that will enhance medial professionalism and appreciation of democratic values in Nigeria.
\end{abstract}

Keywords: Media; Development; Democracy; Governance; Politics.

Cite This Article: Ola Abegunde, and Olatunde J. Fajimbola. (2018). "MEDIA AND DEMOCRATIC GOVERNANCE IN NIGERIA." International Journal of Research - Granthaalayah, 6(11), 94-108. https://doi.org/10.29121/granthaalayah.v6.i11.2018.1093.

\section{Introduction}

Every society operates a form of government for the purpose of maintaining order, peace, security and general well-being of its citizens. In spite of the various forms of government, such as autocracy (government by one) and aristocracy (government by few); democracy, (government by many), despite its imperfection and deficiencies, it is still considered the best. One of the pillars of 
democracy that makes it outstanding and preferable to other systems of government that had existed before it is the entrenchment of free speech and freedom of press.

The ideology of democracy which is based on representation, participation and rule of law is anchored on the ability of the electorates to freely express their interests through available media of communication. The basic social values of the society, including; rule of law, human rights, freedom, wealth creation, liberty, equality, among others are expected to be promoted by the media. The media is also expected to hold the government accountable to the people. In essence, the media is very crucial in any democratic setting in that it serves as the watchdog of the society. This is why it is more dangerous for the media in a democracy to lose its head in unconscionable partisanship (Ogbodo, 2016).

The history of democratic governance has been traced to the general assembly of male citizens in the Greek city-states. The modern concept of democracy finds useful meaning in the context of the speech of the $16^{\text {th }}$ American President, Abraham Lincoln (1809- 1865) at Gettysburg in November 19, 1863, when he conceived it as the system of government of the people, by the people and for the people. The ideology of liberty predicated on John Locke's proposition that all men are created equal also formed the bedrock for institutionalizing the America democracy with the media having a significant role. The media informs and educates the electorates concerning democratic values, and the citizens' rights. It also promotes equality. This is to ensure that every law-abiding and healthy adult is legally entitled to vote and be voted (Igwe, 2007). With the mass media taking the role of information dissemination in democratic society, the mass media has great influence in democratic politics (Roskin, Cord, Medeiros \& Jones, 2015).

The mass media is the agent of political communication that play vital role in the survival of democracy, as well as disenchantment with democracy; since political system and the communication system parallel one another (Roskin, Cord, Medeiros \& Jones, 2015). The media operators traditionally decide which events to report and how to handle the elements in those stories (Janda, Berry and Goldman, 2005). Mass Media is central to institutionalization and survival of democracy anywhere in the world because it serves as a vital link between the government and the governed.

This paper explores the role of the media in democratic governance in Nigeria as well as its challenges. The rest of the paper is presented in four sections which are: introduction, conceptual analysis, literature reviews, theoretical framework, analysis of issues and recommendations. The study is both descriptive and analytical in nature and it relies on secondary sources for generation of data.

\section{Conceptual Analysis}

\subsection{Mass Media}

The mass media refers to organized means of dissemination of fact, opinion, entertainment and other mass media includes newspapers, magazines, radio, television, internet, books and other forms of published materials. Hassan (2013), notes that the term "mass media" refers to the means of public communication reaching a large audience. In sense, mass media are the tools or 
technologies that facilitate dissemination of information and entertainment to a vast number of consumers. Mass media reaches large numbers of people for information, education, persuasive and entertainment reasons. It is a means of communication for interchange of thoughts or ideas.

The mass media plays a pivotal role as agenda setters and also provides avenues for raising conflicts to the level of discussion in a democratic setting. It also functions as a watchdog of a democratic society by bringing to the people the information they need to exercise independent judgment in electing public officials of their choice (www.thetidenewsonline.com). Media and democracy are like Siamese twins because one cannot meaningfully function without the other. In a democratic society, the media, which is synonymous with the press is expected to function as the Fourth Estate of the Realm. Every civilized society or nation has functional media to sustain its democratic system. The economic and technological sector, the political sector, legal and administrative sector, cultural sector has their communication needs upheld through the media (Ndolo, 2011). The media as a means of political communication facilitates dissemination of facts and opinions through the newspapers, magazines, books, films, radio, television, the World Wide Web and other form of publishing (Ndolo, 2011).

The functions of the media in society encompass information dissemination, cultural transmission, entertainment and mobilization. In a democratic setting, the media provides information about local, national and international events and conditions, creates awareness; explains, interprets and comments on the meaning of political events; communicate democratic values, rules and norms of the society to the citizen. This means that the mass media helps politicians to relax by providing amusement, diversion to escape from daily political turmoil and concerns, thereby, reducing political tension that would have been created without information about government policies and programmes.

The category of media in Nigeria that has continuously influenced political system is the elite media. The elite mass media comprises newspapers, magazines, radio and television that are widely circulated and read, listened to or watched by decision makers in Nigeria. The decision makers take the news and editorials of the elite media seriously. The elite media have influence out of proportion to their circulation and they are called the elite media because the people who read them and listen to them are generally wealthier and better educated and have much more influence than readers of hometown papers. Many of the elite media are opinion leaders (Roskin, Cord, Medeiros and Jones, 2010).

Historically, Nigerian media evolved from the work of pioneering missionaries and activists who were committed to social values of peace, justice and welfare. Reverend Henry Townsend, a British missionary pioneered the first newspaper known as Iwe-Irohin on December 3, 1859 in Nigeria. Mr. Robert Campbell in 1863 published the second Newspaper in Nigeria, the AngloAfrican Newspaper. Other pioneers of the Nigerian press include; Mr. Richard Beale Blaize who published The Lagos Times and Gold Coast Advertiser in November 1880, John Payne Jackson published The Lagos Observers, a bi-weekly newspaper that came on the news stand on February 15, 1882. The Mirror newspaper was published on December 17, 1887, Lagos Weekly in March 3, 1891 and Lagos Weekly Record in December 3, 1915 (Mabadeje, 2004).

The Lagos Weekly Record was significant in the history of the Nigerian press for it provided a good training for some Nigerians who later made great impacts in Nigerian democratic governance 
(Mabadeje, 2004). Prominent among them was Ernest Sese Ikoli who established African Messenger newspaper in 1921 and later appointed the first editor of the Daily Times newspaper from 1926 to 1928. After the Lagos Record came Nigerian Chronicle on November 20, 1908, Lagos Standard was also established in 1908 and the Nigerian Pioneer came in 1914. All these newspapers were used to promote governance.

The founding father of nationalism and one of the pioneers of Nigeria democracy, Herbert Samuel Macaulay was a product of the media. He established the Lagos Daily News that was first published in 1925. He used his newspaper for political activities which earned him the accolade of father of Nigerian nationalism (Mabadeje, 2004). The early press (media) in Nigeria sowed the seed of nationalism and democracy. The early media was virile, daring and nationalistic. The main focus of the media was how to awaken citizens' consciousness to join the struggle for independence and anti-colonial rules.

Another democratic leader that was a product of the media was Dr. Nnamdi Azikiwe who ignited the fire of the renewed and sustained agitation for independence with his West African Pilot, which was first published on November 22, 1937. Azikiwe was a catalyst in the quest for Nigeria's political independence through his newspaper. Also, Chief Obafemi Awolowo established Nigerian Tribune which was used to support the struggle for independence. The paper was first published in November, 1949.

However, division among the media circle emerged with the appearance of the broadcast media. The newspaper maintained an anti-colonial posture and orientation, but the broadcast media played the role of supporting the British colonial government to refute allegations from the nationalists as severally published in the newspapers. Radio, as the only electronic medium that existed in Nigeria during the pre- independence struggle, was under the control of the British government and was used as a medium of British propaganda in the country.

\subsection{Governance}

The concept of governance can be deduced from the term, government. Governance is the act or state of governing. Governance is a process of policy formulation, implementation and evaluation; it involves exercise of authority and control over human and material resources in a defined state. Government, however, is a body of people, usually elected, with the powers to control the affairs of a country or state. To govern, therefore, is to control and direct the affairs of a country, state or organization. In a democratic society such as Nigeria, the powers of government are distributed among the Executive, Legislature and the Judiciary. The obligation of the mass media in democracy is to uphold the responsibility and accountability of the government to the people.

The evolution of governance in one form or the other can be linked to emergence of socialization when people decide in the course of history and development to live together for the advancement of their security and welfare. There were many forms of interaction that emerged in different times and places throughout the world history. Although, there may not have been firmly written laws, but governance in the ancient times was guided by norms, rules, established principles and institutions governing relationship among people. In modern age, the pattern of governance is established and stated in the Constitution. 


\subsection{Development}

The essence of democratic governance is development. The media and actors in democratic governance need to function under ideal principle and conceptual framework of development. According to Asemah (2011), development may be seen as the sum total or the outcome of efforts made by the people to improve upon their conditions of living. In this respect, development is seen as being synonymous with growth, advancement and progress. However, development must not be seen only in the terms of material advancement, rather it includes human, economic, political, social development among others.

A society is said to be moving towards development when there is freedom, social justice and opportunities for the people to participate in taking decisions on issues that affect them. This implies that people need to be informed; they need information on the possibilities of improving on their lots and effecting the necessary changes. A climate for development must be created in the environment through education, motivation and mobilization. When this is done, the people for whom a particular development activity is intended would have the opportunity for discussing all aspects of the issue and asking questions such as: what kind of development? development for what? by what means? at what rate and at what cost?

Furthermore, Orewere (2007) posited that development is a package of benefits given to a people by the government. It is the means by which the people of a country progressively acquire a greater mastery over their destiny. Development takes place only when the central problems of poverty, unemployment and inequalities in a society have declined appreciably. This is concerned with the increase in the production of materials, goods and services with the aim of economic growth, reduction of inequality and eradication of poverty. Development is determined by real wealth, capital growth, improved living conditions, changed conditions of existence and changed conditions of relationships between social groups.

Jerry Gana in his paper, True Meaning of Development asserted that the true meaning of development must be conceived as the development of people, the unfolding and realization of the creative potential, enabling people to improve their material conditions of living through the use of resources available. It is a process by which people's personality and creativity are the moving force behind the socio-economic transformation of society (Gana, 1980).

It has been noted that development is not limited to such variables as numbers of good roads, rate of growth of building of skyscrapers and expansion of market square. Apart from the above, development also starts with a positive change of attitude on the part of the people. When people have good material resources and there is no positive change in attitudes, then there is no development; and the individual needs to have increased knowledge, capacity, and aspiration as well greater freedom, creativity, self-discipline, responsibility and material well-being (Asemah, 2011).

Development is the institutionalization of the rule of law, provision and maintenance of basic infrastructure, availability of autonomous and self-regulating institutions of government, establishment of enabling environment and opportunities for self-actualization. 


\subsection{Democracy}

Democracy is a political ideology that is all encompassing and all embracing. Janda, Berry and Goldman (2005) highlighted the ingredients of democracy in all its ramifications and submitted that democracy encompasses freedom, order and equality. Democracy defines what the ideal form of government should exhibit. The purposes of government in democracy are maintaining order, providing public goods and promoting equality. The practice of democracy is also guided by principle or theory. According to Janda, Berry and Goldman (2005), the origins of democratic thought lie in ancient Greek political philosophy in which everyone participated in decision making. Greek philosophers classified governments according to the number of citizens involved in the process of decision making for the society. The classifications include:

1) Autocracy: This is a system in which one individual has the power to make all important decisions for the people. The concentration of power in the hands of one person, usually a monarch was a more common form of government in earlier historical period of Africa.

2) Oligarchy: This system puts government power in the hands of elite. At one time, the nobility or the major landowners commonly ruled as an aristocracy.

3) Democracy: This means the rule by the people. The three classifications can be summarised as a continuum running from rule by one person, through rule by a few, to rule by many.

The word "democracy" originated in the Greek city state around the fifth century B.C. While demos referred to the common people, the masses, kratos meant power. The modern view of democracy implies that the ultimate authority of government is vested in the common people so that public policy is made to conform to the will of the people and to serve the interests of the people. The salient features of democracy are equal participation by all in the common affairs for good life and arriving at public decisions in an atmosphere of free discussion and general respect for law (Gauba, 2005).

Dicey (1905) cite in Gauba (2005) described democracy as a form of government under which the majority opinion determines legislation, while Bryce (1921) cite in Gauba (2005) viewed democracy as the rule of the people expressing their sovereign will through the votes. The assertion of philosophers like Plato, Aristotle, John Austin, James Bryce, Dicey, Lowell and John Seeley was that democracy focuses on the rule of the majority where everyone has a share. In this context, democracy is a system of government that allows for majority participation in state's decision making process; it is a system that allows for unrestricted exercise of fundamental human rights and guarantees rule of law.

\section{Literature Review}

Heywood (2007) explained the connection between media, democracy and governance and therefore questioned whether the media is really working as custodians of democracy. He however stressed that, although media impact on democracy could be for good or ill, in most cases, it has always been for ill in the information age. The media affected the process of governance, particularly in transformation of political leadership, reapportionment of government power and changes to political culture. He also raised concern over the fear that the media attitude towards governance is prone to leading to a growing disenchantment with politics and making societies more difficult to govern. It is pertinent to observe how the Nigerian media celebrates the personal 
lives and private conduct of political leaders, with less emphasis on political issues and national development.

Nigeria was lucky in pre-independence 1960, to have vibrant media that played the role that culminated into independence and establishment of democratic governance. The pre-independence media served as tools of education and enlightenment. However, after independence, regionalism and ethnicity set in and succeeded largely in influencing the perceptions of Nigerian media operators who were inclined towards the interest of their own region. Rather than encouraging the spirit of unity and ideology of one Nigeria, the media output catalyzed loss of grip on nationalism. The people, though of the same national boundary have their attention re-directed towards ethnic and religious pluralism. As rightly pointed out by Mabadeje (2004), when the British, regarded as common enemy vacated the political stage, regionalism took the place of nationalism.

The idea of democratic value that cut across ethnic barriers and regional boundaries was alienated by regional governments that established regional newspapers, radio and television stations, not for the sole purpose of consolidating democracy and promoting national cohesion and development, but for regional and selfish political agenda. The post-independence media were grossly used for articulating and championing of regional and ethnic ideas that have become the root cause of division and underdevelopment of the Nigeria State. In the ultimate analysis, it can be asserted that the Northern Region Government manipulated the Nigerian Citizen newspaper to promote and defend the political interests of the Northern Region; while the Eastern Region manipulated the Nigerian Outlook newspaper, to promote the Eastern political interests, and in the same manner, the Western Regional government established the Sketch newspapers to promote the interests of the Western Region. Therefore, the Nigerian media became a threat to Nigeria's peace, unity, progress and democracy.

In addition, each regional government had established its own broadcast media for the purpose of promoting sectional agenda and for the propaganda of regional powers of leaders and elite groups. The Western Nigeria Broadcasting Service (WNBS), a television station which was established in 1959 and the radio section launched in May, 1960 constituted the instruments of power and propaganda of the West. The Eastern Region established its own radio section on October 1, 1960 for similar purpose. The Northern region commenced its own broadcast media to compete with other regions in 1962. These broadcasting services which served regional interests were dominated by personalized political views resultantly undermined democratic principles and values that should have provided the bedrock for the emergence of a great nation.

It is, therefore, clear that by promoting regional agenda and ethnicity, the Nigerian media covertly or overtly contributed to the dismantling of the first democratic governance, the first coup the and civil war that terminated the administration of the elected civilian government in the First Republic. Although, the media performance in Nigeria in the area of consolidating enduring and ideal democracy is a subject of debate, it is obvious that under oppressive, repressive and regressive leadership, the performance of the media cannot be said to be inspiring. The fundamental role of the media in setting agenda for good governance, effective leadership, participatory governance, free and fair elections remains a challenge in Nigerian democracy. 
Worse still is the fact that the media in Nigeria sends negative signals to the international community through excessive engagement in sensationalism, lack of in-depth investigative reports, corruption; political, religious and ethnic bias. Such incidences have aroused negative attitudes of the public and international community towards Nigerian media. One of the most effective ways to measure the performance of the media is the extent to which they act as the watchdog of the society. However, when the media fails to make government accountable to the people, democracy is at stake in such society.

Against the above background, it has been discovered that some Nigerian media operators are agents of the elite groups that constitute the political gladiators. The media organizations served the interest of the rich in the society. They are sometimes less sensitive to the plights of the masses unless the plights further improve media economy. According to Mimiko (2007) Nigerians grapple with at least three developmental challenges; and the media are unreliable partner to support the masses to solve:

1) the challenge of how to build an attitudinally-unified entity from the array of ethno-national allegiances that currently define the country, with a view to maintaining a degree of political stability conducive to democratic governance and economic development.

2) The challenge of how to free the economy from the stranglehold of non-performing but overbearing state and allow the market a degree of autonomy without which growth and development may continue to be elusive.

3) The challenge of how to legitimize the governance structure in the country by so doing end alienation, bring down corruption and enhance the delivery capacity of the Nigeria State (Mimiko, 2007).

In effect, the media role in bringing these challenges to national consciousness and engage in constant discussion for effective solution is missing. The 1999 Constitution of the Federal Republic of Nigeria spelt out the obligations of the mass media: "Press, Radio, Television and other Agencies of the Mass Media shall at all times be free to uphold the fundamental objectives contained in this Chapter and uphold the responsibility and accountability of the Government to the people" (1999 Constitution, Section 22). The media in Nigeria has failed to hold various governments accountable in the light of corruption, bad leadership and decayed social infrastructure.

\section{Theoretical Framework of Analysis}

\subsection{Political Communication Theory}

In their work Political Communication in Africa, Olukotun and Omotoso (2017) assert that there is a limited application of communication theory to the heart of politics in countries of Africa, thereby making African politics speculative. Despite the fact that communication is central to democratic governance, the political class pays very little attention to understanding its interconnection with political system. As noted by Fajimbola (2017) inability to understand and apply effective political communication to African politics has resulted into the image dilemma of most African countries. Also, lack of political communication is largely responsible for the low political culture of most of the countries on the continent, by extension, this makes powerful individuals the centre of political activities in various countries of the continent. 
Communication is the process of transmitting information from one individual or group to another; from the government to electorate; from electorate to government; and from one country to another. Communication is the activity that helps to improve and sustain political relationship in democratic society. Communication is the expression of ideas, thoughts, feelings and desires through the means of mass media.

Medium of communication can be intra-personal, inter-personal, small group, large group communication, or mass media. This paper is concerned with the mass media form of communication. All forms of communication share experiences from a source, through a channel, to a receiver. Communication is therefore, making common certain knowledge (Okunna, 2002). Communication is both an ideological and cultural creation. This is understood to show that, in communication, meanings are understood within the context of a people's taste, values, norms, and philosophy. Exchange of meaning in communication is, however, most pronounced in international communication where a cross current of inter-cultural interaction has been made possible by discoveries in the communications field (Okunna, 2002).

In his work, The Nerves of Government: Models of Political Communication and Control, published in 1963, Deutsch used communication approach to study the most significant activity in political process, the bedrock of political system and the continuous flow of political system. Gauba (2005) further studied Deutsch's Communication theory which combined the concepts and methods of modern information technology as well as physiology of the nervous system to an analysis of political system. With his introduction of the techniques of cybernetics to the sphere of political analysis, Deutsch has been able to explain communication process in political environment. Cybernetics is the study of the operation of control of communication systems that deal both with biological systems and man-made machinery. The intention of Deustch was to understand how communication functions like nerves in the body-politic, how communications affect and influence decision making process. Deustch, from the onset, declared that "his work was concerned less with the bones or muscles of the body-politic than with its nerves- its channels of communications and decision" (Gauba, 2005:98).

Communication theory is hinged on understanding the function of communication as the centrepiece of all political activity. An analysis of communication flowing from and flowing into political system focuses on the description, classification, analysis and explanation of the important aspects of political life; the argument of Deutsch therefore in proposing Communication theory of political system is centre on the need to begin to perceive the various problems of politics as that of deficiency or inefficiency in steering the political life along the ideal route or smooth path, rather than looking at the problems as power relation. Deustch's assertion that political system should be regarded as a network of communication channels is based on the assumption that a self-regulating or self-controlling system evolves its own processes and mechanisms for the acquisition, collection, transmission, selection and the storage of information. In interpreting Deutsch's theory of Political Communication, Davies and Vaughan (2007) noted that:

The members of the political system come to acquire mechanisms for the transmission of messages (media) and for the coordination and control of the channels of communication (media operators). The cohesion of a political system can be analyzed in terms of the degree to which these coordination and control mechanisms continue to function properly (media performance) - to adapt 
themselves, in the context of the goals which they set to the information which they receive from various sources; even to modify which they set themselves (Agenda- Setting).

The criticism of the Communication theory, however, is its limitation as an approach in political science. In political science, Communication theory is particularly useful for an analysis of the process of bargaining, conflict-resolution, and decision-making, evaluation of policies, estimating the impact of publicity and propaganda as well as for understanding the dynamics of international relations. But it is inadequate as an approach in the analysis of power structure of society, ideologies, allocation of resources, or in explaining the phenomenon of violence and revolution (Gauba, 2005).

\subsection{Agenda Setting Theory}

The main task of the media in democratic governance is to report the news that promotes democratic activities, and to cover political events. The media is expected to have the firsthand information and is required to be on the scene of events through its news reporters, journalists and agents. The media works to bring to the awareness of the public various significant political events that occur in different parts of the country. Some of the reporters are assigned to cover the President, National Assembly, Governors, State Houses of Assembly, Local Governments and Political arena where democratic information are generated. Apart from reporting the news, media operators interpret and present the news. Through the interpretation and presentation of the news, the media influences public opinion. However, Janda, Berry and Goldman (2005) noted that the greatest influence of the media on politics is found in their power to set political agenda which is defined as a list of issues that people identify as needing government attention. In this way, the media influences considerably which issues government decision makers should discuss and debate.

In expatiating on Agenda-Setting theory of the media, Popoola (2017) affirms that in every democratic society, topical issues of the moment to be discussed either on radio, television, newspapers, magazines, as well as online publications are always determined by the media. The consequence of this proactive media tendency makes the public tend to think about such issues that are given prominence as important issues which need thoughtful reactions of the public. Hence, the media often allocates different proportion of space in print or time on electronic media for different issues to reflect their significance and value, or importance to the general public. If the media fails to give considerable attention to particular issues, members of the public are likely to consider such issues as not very important and significant. As such, the media functions as agenda setting mechanism.

Agenda setting theory is the consequences of what the mass media does, whether intended or not. Agenda setting theory is, therefore, the process whereby the mass media determines what people think and worry about (McQuail, 2008). The history of agenda setting theory first began with Walter Lippmann who observed this function. Walter Lippmann (1922) observed that people do not deal directly with their environment as much as they respond to pictures in their heads. He concluded that the real environment is altogether too big, too complex, and too fleeting for direct acquaintance. Therefore, the people need not equipped to deal with the much subtlety, so much varieties, so many permutations and combinations of the environment. Although people have to 
act in that environment, the environment has to be reconstructed on a simpler model before the people can manage it (Lippmann, 1922).

Cohen (1963) actually made use of the term, agenda-setting and refined Lippmann's ideas into the theory of agenda-setting by writing that the media may not be successful much of the time in telling people what to think, but it is stunningly successful much of the time in telling people what to think about. It follows from this that the world looks different to different people, depending not only on their personal interests, but also on the map that is drawn for them by the writers, editors, and publishers of the papers they read (Cohen, 1963: 13). This means that the media is rarely successful in telling people what to think, but then, scholars say that, the world looks different to different people depending on what the media offers them (Baran \& Davis, 2012).

Maxwell McCombs and Donald Shaw (1996) critically examined this proposition. McCombs and Shaw described agenda setting function in the research, Emergence of American Political Issues. They pointed out that there is abundantly collected evidence that editors and broadcasters play important role as they go through their day-to-day tasks in deciding and publicizing news. This influence is the ability of the media to effect cognitive change among individuals, and to structure thinking. It is also the ability of the media to mentally order and organize the world for the people. McCombs and Shaw pointed out that the mass media may not be successful in telling the people what to think, but they are stunningly successful in telling them what to think about (McCombs and Shaw, 1996 cited in Baran and Davis, 2012)).

Agenda setting theory has two levels of analysis. The first level enacts the common subjects that are most important, and the second level decides what parts of the subjects are important. According to Rogers and Dearing in their book on Agenda Setting Research, the first part of the agenda setting process is the importance of the issues that are going to be discussed in the media. Second, the issues discussed in the media have an influence over the way the public thinks. This second part is referred to as public agenda. Ultimately the public agenda influences the policy agenda. The media agenda affects the public agenda, and the public agenda affects the policy agenda (Littlejohn, 1996).

McCombs and Shaw brought the importance of agenda setting to attention in the Chapel Hill study. They asserted that the agenda issues found in the news media and among the general public is what sets the media agenda. Other factors that affect agenda setting are media gatekeepers, news editors and media managers as well as external influences. The external influences are non-media sources such as government officials, international relations actors, and influential individuals (Litlejohn, 1996).

The assumption of agenda setting theory is that the ability of the media to influence the visibility of events in the public mind has been a part of culture. Therefore, agenda setting theory helps the media to selectively choose what the people will see or hear. There are two basic assumptions underpinning the agenda setting theory.

1) The press and the media do not reflect reality; they filter and shape it;

2) Media concentration on a few issues and subjects leads the public to perceive those issues as more important than other issues (Litlejohn, 1996). 
The theory is relevant in analyzing and explaining the role of the media in Nigerian democracy, in that the media sets the pace and focus of the public on political issues. However, the Nigerian media can help the nation by setting political agenda for positive development, transformation, good governance, democratic norms and effective leadership. In Nigeria, the media can help the development of the country by focusing on political, economic and social problems that will draw the attention of policy makers and compel them to initiate and execute policies in solving the identified problems. The agenda of development setting by the media will invariably inspire the citizens to appreciate the values of democracy.

\subsection{Challenges of Nigerian Media in Democratic Governance}

There are many challenges confronting the media in a democratic setting. The major challenge is linked to the nature of the media system that is in operation in a country. It is important to note that in the Nigeria situation, the media system appears to be operating under "autocraticdemocratic" governance. As Ekeanyanmu (2008) pointed out, because most Nigerian leaders are authoritarian in their approach to governance, the Nigerian media willingly or unwillingly supports and advances the policies dictated by the ruling elite without subjecting them to critical and public scrutiny. The government designs various means to put the media under its control. Although, private ownership of the media in Nigeria is permitted, the content and purpose of the media output still suffer from self or official censorship, since the media owners are mostly part of the actors in the political economy. The public media on the other hand is at the mercy of government that establishes them. Operators of Public or Government owned media see themselves as official megaphones of any government in power.

This perspective shows that media freedom is mostly adjudged as freedom guaranteed and interpreted in the interest of the elite. Specifically, the media operation in an authoritarian democratic environment is not free, but will at best be the extension of government propaganda.

Furthermore, economic interest has forced the media professionals and the media industry to play along with the dominant power, while political interest has subjected media ethics to government dictates, hence, politics is hereby restraining the independent and freedom of the media. In authoritarian political environment, the media professionals will be willing or unwilling tools of support to the interests or forces that employ and pay them. They do so in order to maintain their jobs and eke out a livelihood (Ekeanyanwu, 2013).

In Nigeria, both in principle and in terms of actual practice, the private media owners who are within the ranks of politicians and business class constitute challenges to professionalism of journalists. Some query the assertion of the institution of the media as the Fourth Estate of the Realm in Nigerian context. In practice, most members of the media could neither act as watch dog nor bark when wrongs are being perpetrated in the system; they even lick the boots of corrupt politicians and share in their proceeds in form of patronage and brown envelopes. The media practitioners do 'kill news' that negatively affects the interest of their proprietors or present such in a favourable manner or not even report such at all. Akinfeleye, (2003) and Ndolo, (2011) cautioned that the media may constitute themselves as the Fourth Estate of the Wreck of democracy in Nigeria. 
In democratic dispensation, the media, though has ethical standard to protect, professional ethics as the moral code of conduct of Journalists are not strictly adhered to in the practice of the profession. In a way, Nigerian media practitioners engage in character assassination, abuse of confidentiality of sources, sycophancy, editorial speckle, bowing to undue pressure, bribery, sensationalism, brown envelope syndrome, bribery and plagiarism. One implication of this development is that it compromises media integrity, media content, and media value and also diminishes the respect expected from the public towards the media institution.

Nigerian media has also been described as an institution operating in a bad shape because of the inability to pay staff salaries, low copy sales, crippling sycophancy, massive shutdown of media houses, poor welfare packages, which eventually lead to ineffective performance of the role of the media as watchdog of the society (Oba, 2017). Another major challenge of the media in Nigeria is the involvement of non professionals in the profession. Unemployment and poverty are essentially responsible for the infiltration of the profession as a means to an end for the poor and the unemployed.

\section{Conclusion}

This study contends that Nigerian media has great responsibility to set public agenda that will enhance the realization of good life in Nigerian democratic settings. It observes that the performance of the media in Nigeria democracy is below expectation as they could not influence attainment of democratic values, such as effective leadership, good governance and human rights. The media has constitutional and moral responsibility towards the promotion of democratic governance, and could use the power of agenda-setting to transform Nigeria.

\section{Recommendations}

In the light of the identified challenges of media in Nigerian democracy, the following are hereby recommended:

The first is adequate training of media stakeholders and political actors in all-embracing political education that will enhance appreciation of democratic values. Media personnel should be trained and certified journalists that are well informed of the ethics of the profession should be the only ones to be allowed to function. Also, proprietors on the other hand are to abide by the rules of engagement.

Second, the media should focus on issues of good governance, improved standard of living for the people through the media content that encourages provision of social facilities such as good roads, electricity and regular power supply. The media should engage in performance level evaluation of public office holders to constantly reveal their performance to them and the public.

Third, the media should call government attention to the challenges in the democratic setting. The media expected to bring to the fore the infrastructural challenges confronting the citizens through periodic reporting till necessary attention are given to such. 
Fourth, the Nigerian media should imbibe the culture of accurate news reporting, non-partisanship and objectivity in presentation of issues. Professional conduct of media practitioners will entrench democratic stability and development.

Five is that media should make government to be more accountable to the people in accordance with their Constitutional role. When the media covers and report all government activities to the public, the government will be forced to be accountable and also perform its responsibility to the public.

Sixth, the media should be free and behave responsibly in promoting democratic values. Freedom of press should be guarantee and media should behave responsibly as the watchdog of government and promoter of democratic values.

\section{References}

[1] Akinfeleye, R. (2003). Fourth Estate of the Realm or Fourth Estate of the Wreck: Imperatives of Social Responsibility of the Press. Lagos: Malthouse Press.

[2] Aliede, J. (200). Exploring the Synergy Between the Application of Press Laws by Media Practitioners, Effective Performance and Contribution to National Development. In N.

[3] Okoro (Ed.), Contemporary Reading in Media and Communication Studies. Lagos: St. Benedette Publishers Ltd.

[4] Asemah, E.(2011). Selected Mass Media Themes. Jos: Matkol Press.

[5] Awosan, J.A. (1980). Currents of thought in African Sociology and the Globa Community. How to Understand Research Findings in the Context of Sociological Perspectives. www.universalpublishers.com/book.php?method=ISBN\&book=1599429993. (accessed 28-062018)

[6] Azikiwe, N. (1987). Pioneer Heroes of the Press. Speech Delivered at the Official Opening of the Nnamdi Azikiwe Press Centre, Dodan Baracks, Lagos.

[7] Baran and Davis (2012). Mass Communication Theory; Theory Foundations, Ferment and Future. www.worldcat.org/title/mass-communication-theory-foundations. (accessed 10-09-2018)

[8] Cohen, B.C. (1963). The Press and Foreign Policy; Princeton University Press. https://books.google.com > Political Science > General. (accessed 10-08-2018)

[9] Ekeanyanwu, N. (2013). International Communication: An Introduction. In N. Okoro (Ed.), Contemporary Reading in Media and Communication Studies. Lagos: St. Benedette Publishers Ltd.

[10] Ekeanyanwu. N.(2008). Political Communication in Africa. In Ayo Olutokun edition. https://www.springer.com/gp/book/9783319486307. (accessed 15-08-2018)

[11] Federal Republic of Nigeria 1999 Constitution. Amendments 2011.

[12] Fajimbola, O.J.(2017). Media, Propaganda, and the Image Dilemma of African State; Political Communication in Africa. https://www.springer.com/gp/book/9783319486307 (accessed 10-082018)

[13] Guaba, O. (2005). An Introduction to Political Theory. India: Macmillan India Ltd. webservices.searchco.nl/tical-the/political-theory-by-o-p-gauba-in-english.pdf. (accessed 20-06 2018)

[14] Hassan, S. (2013). Mass Communication Principles and Concepts. New Delhi: CBS Publishers.

[15] Igwe, O. (2007). Politics and Globe Dictionary. Aba: Eagle Publishers.

[16] Janda, K., Berry, J \& Goldman, J. (2005). The Challenge of Democracy. New York: Harold Burch.

[17] Littlejohn, S. W. (1996). Theories of Human Communication; International Student's Edition; Wadsworth Series in Communication Studies. https://books.google.com > Language Arts \& Disciplines > Communication Studies (accessed 28-06-2018) 
[18] Mabadeje, I. (2004). The Nigerian Press Under the Military: A Compendium of Cases of Press Freedom Violations in Nigeria (1966-1999). Uyo: Robertminder International Ltd.

[19] Mimiko. O. (2007). To Live with Happiness: An Anatomy of Election Rigging, Peaceful Resolutio and Restitution in Ondo State. www.africanbookscollective.com/books/to-live- with-happiness (accessed 10-06-2018)

[20] Mimiko, O. (2010). Swimming Against the Tide: Development Challenge for the LongDisadvantaged in a Fundamentally Skewed Gglobal System. Obafemi Awolowo University, IleIfe, Nigeria. Inaugural lecture series 233.

[21] McQuail, D. (2008). Mass Communication Theory. 4 Theory of Media, Society and Culture. Connection and Conflicts. uk.sagepub.com/en-gb/eur/mcquails-mass-communicationtheory/book234219 (accessed 28-06-2018)

[22] Maxwell McCombs and Donald Shaw (1997). Communication and Democracy; Exploring the Intellectual Frontier in Agenda Setting Theory. https://masscommtheory.com/theoryoverviews/agenda-setting-theory/(accessed 10-08-2018)

[23] Ndolo, I. (2011). Contemporary Issues in Communication and Society. Enugu: Rhyce Kerex Publishers.

[24] Oba, W. (2017). NGE, Media and Democracy. Thenationonlineng.net/nge-media-democracy. (accessed 15-07-2018)

[25] Ogbodo, A. (2016). The Media and Democracy in Nigeria. https://m.guardian.ng/opinion (accessed 10-07-2018)

[26] Okoro, N. \& Okolie, A. (2004). Law, Politics and Mass Media in Nigeria. Nsukka: Prize Publishers Ltd.

[27] Okunna, C.S. (2002). Teaching Mass Communication-a Multidimensional Approach; Enugu NewGenerationBookswww.scirp.org/(S(lz5mqp453edsnp55rrgjct55))/reference/References Papers.aspx?... (accessed 18-07-2018)

[28] Olukotun, A. and Omotoso, S.A. (2017). Political Communication in Africa. In Ayo Olukotun Edition . https://www.springer.com/gp/book/9783319486307. (accessed 15-08-2018)

[29] Popoola, O. (2017). When we Speak of Noting. Cassava Republic Press. https://brittlepaper.com/2017/08/.(accessed 15-10-2018)

[30] Roskin, M., Cord, R. \& Jones, W. (2015). Political Science: An Introduction. New York: Pearson.

[31] The Tide. (2017). The Media and Democracy in Nigeria. www.thetidenewsonline.com (accessed 28-06-2018)

[32] Walter lippmann (1922). Public Opinion; Wading River, Long Island. www.wwnorton.com/college/history. (accessed 10-07-2018)

*Corresponding author.

E-mail address: ola_dunjoye@ yahoo.com 